Article

\title{
Anticancer Activity of Novel Plant Extracts and Compounds from Adenosma bracteosum (Bonati) in Human Lung and Liver Cancer Cells
}

\author{
Ngoc Hong Nguyen ${ }^{1}\left(\mathbb{D}\right.$, Qui Thanh Hoai Ta ${ }^{2}{ }^{\oplus}$, Quang Thang Pham ${ }^{3}$, Thi Ngoc Han Luong ${ }^{3}$, \\ Van Trung Phung ${ }^{4}$, Thuc-Huy Duong ${ }^{5}$ and Van Giau Vo ${ }^{6,7, *(1)}$ \\ 1 CirTech Institute, Ho Chi Minh City University of Technology (HUTECH), Ho Chi Minh City 700000, \\ Vietnam; nn.hong@hutech.edu.vn \\ 2 Institute of Research and Development, Duy Tan University, Danang 550000, Vietnam; \\ tathoaiqui@duytan.edu.vn \\ 3 Institute of Applied Science, Ho Chi Minh City University of Technology (HUTECH), \\ Ho Chi Minh City 700000, Vietnam; pquangthang1@gmail.com (Q.T.P.); ngochanlt96@gmail.com (T.N.H.L.) \\ 4 Center for Research and Technology Transfer, Vietnam Academy of Science and Technology, \\ Hanoi 100000, Vietnam; pvtrung@ict.vast.vn \\ 5 Department of Organic Chemistry, University of Education, Ho Chi Minh City 700000, Vietnam; \\ huydt@hcmue.edu.vn \\ 6 Bionanotechnology Research Group, Ton Duc Thang University, Ho Chi Minh City 700000, Vietnam \\ 7 Faculty of Pharmacy, Ton Duc Thang University, Ho Chi Minh City 700000, Vietnam \\ * Correspondence: vovangiau@tdtu.edu.vn
}

Academic Editors: José Antonio Lupiáñez, Amalia Pérez-Jiménez and Eva E. Rufino-Palomares Received: 30 May 2020; Accepted: 16 June 2020; Published: 24 June 2020

\begin{abstract}
Cancer is the second leading cause of death globally, and despite the advances in drug development, it is still necessary to develop new plant-derived medicines. Compared with using conventional chemical drugs to decrease the side effects induced by chemotherapy, natural herbal medicines have many advantages. The present study aimed to discover the potential cytotoxicity of ethanol extract and its derived fractions (chloroform, ethyl acetate, butanol, and aqueous) of Adenosma bracteosum Bonati. (A. bracteosum) on human large cell lung carcinoma (NCI-H460) and hepatocellular carcinoma (HepG2). Among these fractions, the chloroform showed significant activity in the inhibition of proliferation of both cancerous cells because of the presence of bioactive compounds including xanthomicrol, 5,4'-dihydroxy-6,7,8,3'-tetramethoxyflavone, and ursolic acid which were clearly revealed by nuclear magnetic resonance spectroscopy $\left({ }^{1} \mathrm{H}-\mathrm{NMR},{ }^{13} \mathrm{C}-\mathrm{NMR}\right.$, Heteronuclear Multiple Bond Coherence, and Heteronuclear Single Quantum Coherence Spectroscopy) analyses. According to the radical scavenging capacity, the 5,4'-dihydroxy-6,7,8,3'-tetramethoxyflavone compound (AB2) exhibited the highest anticancer activity on both NCI-H460 and HepG2 with $\mathrm{IC}_{50}$ values of $4.57 \pm 0.32$ and $5.67 \pm 0.09 \mu \mathrm{g} / \mathrm{mL}$ respectively, followed by the ursolic acid with the lower percent inhibition at $13.05 \pm 0.55$ and $10.00 \pm 0.16 \mu \mathrm{g} / \mathrm{mL}$, respectively $(p<0.05)$. Remarkably, the AB2 compound induced to significant increase in the production of reactive oxygen species accompanied by attenuation of mitochondrial membrane potential, thus inducing the activation of caspase- 3 activity in both human lung and liver cancer cells. These results suggest that $A$. bracteosum is a promising source of useful natural products and AB2 offers opportunities to develop the novel anticancer drugs.
\end{abstract}

Keywords: Adenosma bracteosum; extract; anti-cancer; cell line; isolated compounds; caspase-3 


\section{Introduction}

A major problem of public health, cancer is one of the main causes of death globally. The prevalence of this disease is rising, however, more rapidly in Africa, Asia, and Central and South America that make up about $70 \%$ of cancer deaths in the world [1]. Many studies have been focusing on the development of agent for cancer therapies [2-4]. The chemotherapy is one of the ways to treat this disease and the advances in anticancer drugs have improved patient care. Unfortunately, the conventional chemical drugs also cause adverse side effects on normal cells/tissue, such as bone marrow function inhibition, nausea, vomiting, and alopecia $[5,6]$. On the other hand, natural antioxidants and many phytochemicals have been recently suggested as anti-cancer adjuvant therapies because of their anti-proliferative and pro-apoptotic properties [3,4]. Hence, the continuing search for anticancer agents/compounds from plants played a critical role to find the possible ways to have safe and to decrease the side effects induced by chemotherapy since natural herbal medicines have many advantages [7-10].

Over several decades, around 200 new chemical compounds have been approved to fight cancer, $50 \%$ of that come from structurally originally natural products and their modifications to be safe and have many advantages [11,12]. Owing to their structural diversity, organic molecules (e.g., terpenes, flavonoids, alkaloids, lignans, saponins, vitamins, glycosides, oils, and other secondary metabolites) play a vital role in selective inhibition of proliferation and induction of cancerous cell death $[13,14]$. Among methoxylated flavones, xanthomicrol was first identified [15] and isolated from Dracocephalum kotschyii Boiss [16] which was able to inhibit proliferation of a number of malignant cells $[16,17]$ because of its inhibition of endothelial cell proliferation via decreased vascular endothelial growth factor activity [18]. In terms of ursolic acid's anti-cancer effect, many studies reported that the underlying mechanisms were the inhibition of tumorigenesis and cancer cell proliferation, as well as apoptosis modulation, cell cycle arrest prevention, and autophagy promotion through in vitro and in vivo models [19-23]. As part of the continuing investigation on natural antitumor from herbs, Bai et al. 2010 first isolated 5,4'-dihydroxy-6,7,8,3'-tetramethoxyflavone from the aerial parts of Rabdosia rubescens, which was able to exhibit cytotoxicity in a various of cancer cell lines, however, the exact mechanisms of its health benefits are unclear [24].

Adenosma bracteosum Bonati (A. bracteosum) belongs to the family Scrophulariaceae, and is used in the treatment of liver diseases because it contains around twelve compounds of essential oil such as thymol $(25.6 \%)$, linalool $(13.1 \%)$, and $(E)-\beta$-farnesene $(9.5 \%)$, etc., $[25,26]$. Although this plant is reported as an efficient medicinal plant, the cytotoxicity against lung and liver cancers and the response of cell lines to the plant extract have not been described. The present study aimed to discover cytotoxic and apoptotic potential of ethanol extract and its derived fractions (chloroform, ethyl acetate, butanol, and aqueous) as well as isolated compounds of $A$. bracteosum on human large cell lung carcinoma (NCI-H460) and hepatocellular carcinoma (HepG2).

\section{Materials and Methods}

\subsection{Chemicals and Reagents}

Camptothecin, DMSO (dimethyl sulfoxide), ethanol, FBS (Fetal bovine serum), HEPES, glucose, L-glutamine, phenol red, sodium bicarbonate, sulforhodamine-B, streptomycin were purchased from Sigma-Aldrich (St. Louis, MO, USA). n-hexane, ethyl acetate, chloroform, silicagel, methanol, trichloroacetic acid, and TLC were purchased from Merck (Darmstadt, Germany).

\subsection{Plant Material, Extraction, and Isolation}

The aerial part of A. bracteosum was collected in December 2018 from Ba Den Mountain, Tay Ninh province, Vietnam. A voucher specimen (No. UH-B02) was deposited in the herbarium of the CirTech Institute, Ho Chi Minh City University of Technology (Vietnam). Total of $7 \mathrm{~kg}$ of the shade-dried and powdered aerial part of $A$. bracteosum $(7 \mathrm{~kg}$ ) was mashed in ethanol $70 \%$ for 2 days. To obtain $800 \mathrm{~g}$ of crude ethanol extract, the solution was filtered, followed by removing of solvent under reduced 
pressure. To obtain aqueous, $\mathrm{n}$-hexane, chloroform $(\mathrm{CHCl} 3)$, ethyl acetate (EtOAc), and n-butanol fractions, these extracts were then suspended in DW and successively partitioned with the solvents, respectively. The chloroform extract (104.6 g) was applied to normal phase silica gel CC, and eluted

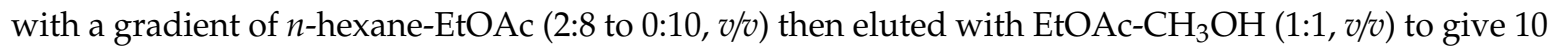
fractions (A1-10). Fraction A7 (35.5 g) was fractionated in the same manner as mentioned previously to afford eight subfractions A7.1-8. Purifying the subfraction A7.4 $(5.5 \mathrm{~g})$ by CC provided seven fractions (A7.4.1-7). Fraction A7.4.1.4 was rechromatographed by CC using the mixture of $n$-hexane- $\mathrm{CHCl}_{3}(2: 8$, $v / v)$ as mobile phase to afford compound AB1 $(135 \mathrm{mg})$. Likewise, multiple purification of fraction A7.4.1.5 by CC yielded compound AB2 (172 mg) and AB3 (127 mg).

\subsection{Free Radical Scavenging Activity Assay}

The samples were measured using the stated method for the 2,2-diphenyl-1-picrylhydrazyl (DPPH) assay [27]. A total of $50 \mu \mathrm{L}$ of sample solutions were used to react with $2 \mathrm{~mL}$ of DPPH• of 6-5 M in $80 \%$ methanol. All samples were scanned at the absorbance wavelength $(515 \mathrm{~nm})$ after $16 \mathrm{~min}$. The \% of DPPH• radical inhibition was calculated using the following equation: \% Inhibition $\left.=\left[\left(\mathrm{A}_{C(0)}-\mathrm{A}_{S(\mathrm{t})}\right) / \mathrm{A}_{C(0)}\right)\right] \times 100$, where $\mathrm{A}_{C(0)}$ and $\mathrm{A}_{C(\mathrm{t})}$ observed at $\mathrm{t}=0$ and $16 \mathrm{~min}$, respectively.

\subsection{Assessment of ABTS Radical Scavenging Activity}

A previous procedure [28] was used to test the radical scavenging activity of the samples. Briefly, ABTS-2,2'-azino-bis(3-ethylbenzothiazoline-6-sulfonic acid) was dissolved in water, reacted with potassium persulfate $(2.45 \mathrm{mM})$ to obtain the working solution. A $1.0 \mathrm{~mL}$ of the working solution was mixed with $10 \mathrm{~mL}$ samples and measured at $734 \mathrm{~nm}$ after $6 \mathrm{~min}$. Ascorbic acid was used as positive control.

\subsection{Brine Shrimp Lethality Bioassay}

The cytotoxic activity of the samples (the ethanol and aqueous crude extracts, chloroform, ethyl acetate, n-butanol, and aqueous fractions and the isolated compound) was determined using the Brine shrimp lethality bioassay $[29,30]$. Briefly, brine shrimp eggs (Artemia salina) were incubated in a vessel containing sterile artificial seawater produced by dissolving $38 \mathrm{~g}$ of table salt in $1 \mathrm{~L}$ of distilled water at 28-30 ${ }^{\circ} \mathrm{C}$ with good aeration (using air pump), under a continuous light condition (60 W lamp) for $48 \mathrm{~h}$. After hatching, nauplii were collected with a Pasteur pipette, ten brine shrimps were moved into each well containing the seawater.

Sample stock solutions were made by dissolving $5 \mathrm{mg}$ of each sample in $1 \mathrm{~mL}$ of DMSO. Test solutions of different concentrations $(1000,800,400,200,100,50,25,12.5$, and $6.25 \mu \mathrm{g} / \mathrm{mL}$ ) were collected using the serial dilution technique with seawater. The solutions were transferred to individual vials and $5 \mathrm{~mL}$ of the seawater including 10 nauplii shrimp were taken into each vial. A control group comprising same volumes of DMSO (as in the sample vials) and 10 nauplii in $5 \mathrm{~mL}$ of artificial seawater was used. After $24 \mathrm{~h}$, the vials were examined with a magnifying glass and the amount of nauplii survived in each vial was counted. The percent mortality of the brine shrimp nauplii was determined for control and increasing concentration from the data and the values of the $\mathrm{LC}_{50}$ were determined. Potassium dichromate was used as a reference standard.

\subsection{Cell Culture and Sulforhodamine B Assay}

The NCI-H460 and HepG2 were grown in Dulbecco's Modified Eagle Medium (DMEM) containing (1\% penicillin/streptomycin, $1 \%$ L-glutamine, and 10\% FBS) and were incubated consecutively in culture flasks $\left(37^{\circ} \mathrm{C}\right.$ and $5 \% \mathrm{CO}_{2}$ ). The sulforhodamine $\mathrm{B}$ (SRB) assay was performed to determine the cytotoxicity effect of the extract, fractions and compounds as previously described [31,32]. Briefly, the cells at $7.5 \times 10^{3}$ cells $/ \mathrm{mL}$ were seeded in a transparent 96-well plate (Falcon, Franklin, NJ, USA) and incubated $\left(37^{\circ} \mathrm{C}\right.$ and $\left.5 \% \mathrm{CO}_{2}\right)$ for $24 \mathrm{~h}$. Then, the old DMEM medium was replaced by $100 \mu \mathrm{L}$ 
of the crude extract and its fractions or camptothecin at different concentrations $(100,75,50,30,20$, $10,5,2.5,1.0$, and $0.5 \mu \mathrm{g} / \mathrm{mL}$ ), followed by incubation at $37^{\circ} \mathrm{C}$ for $48 \mathrm{~h}$. Subsequently, the treated and non-treated cells were fixed by adding $50 \mu \mathrm{L}$ of cold trichloroacetic acid $50 \%$ and incubated for $1 \mathrm{~h}$ at $4{ }^{\circ} \mathrm{C}$. The plates were washed with distilled water, air dried, and stained with $0.2 \% \mathrm{SRB}$ (20-30 $\mathrm{min}$, room temperature). The plates were then washed with $1 \%$ acetic acid to remove unbound dye. After air-drying, $200 \mu \mathrm{L}$ Tris-base $10 \mathrm{mM}$ was added to each well. The plates were shaken in ELISA photometer for $20 \mathrm{~min}$ and absorbance was measured at wavelength of $492 \mathrm{~nm}$ and a reference wavelength of $620 \mathrm{~nm}$. The effect on the cell growth was calculated as:

$$
\mathrm{I} \%=1-[\mathrm{OD}(492-620) \text { sample / OD }(492-620) \text { blank }]) \times 100 \%
$$

where $\mathrm{I} \%=\%$ growth inhibition; $\mathrm{OD}=$ optical density. In addition, the $\mathrm{IC}_{50}$ values (the concentration corresponding to $50 \%$ cell-growth-inhibition rate) were also determined on the basis of linear-regression analyses.

\subsection{DNA Fragmentation and Apoptosis Induced by AB2}

In order to analyze DNA fragmentation, NCI-H460 and HepG2 cells were induced apoptosis by treating with $\mathrm{AB} 2$ at $\mathrm{IC}_{50}$ and $2 \times \mathrm{IC}_{50}$. DNA purification kit was applied to extract DNA, according to the manufacturer's instructions (Thermo Fisher Scientific, CA, USA). Passing quantification, $2 \mu \mathrm{g}$ of each DNA sample was loaded to electrophoresis on a 1.5\% agarose gel, then the gel was photographed under ultraviolet illumination after staining with ethidium bromide $(10 \mu \mathrm{g} / \mathrm{mL})$.

The effect of AB2 on cell apoptosis was evaluated by flow cytometer with Annexin V-FITC/PI staining kit (Thermo Fisher Scientific, CA, USA), according to the manufacturer's instructions. Briefly, the cells were treated with AB2 compound at IC50 and $2 \times$ IC50 concentrations for $24 \mathrm{~h}$. After harvesting, cells were suspended in $300 \mu \mathrm{L}$ binding buffer, and then stained with Annexin-FITC and/or propium iodide. Positive controls for apoptosis were stained with only Annexin-FITC. Positive controls for necrosis were stained with only propium iodide. At least $10^{4}$ cells were analyzed by flow cytometer (BD, Biosciences, San Jose, CA, USA) and data were analyzed using FlowJo vX.0.7 (Tree Star, Inc., Ashland, OR, USA).

\subsection{Detection of Mitochondrial Membrane Potential}

The changes in mitochondrial membrane potential were determined using TMRE (tetramethylrhodamine, ethyl ester) mitochondrial membrane potential assay kit (Abcam, Cambridge, UK), according to the manufacturer's instructions. Briefly, NCI-H460 and HepG2 cells in 96-well plate at $1 \times 10^{4}$ cells per well were incubated for $24 \mathrm{~h}$. Cells were treated with AB2 compound at $\mathrm{IC}_{50}$ and $2 \times \mathrm{IC}_{50}$ concentrations for $24 \mathrm{~h}$. After incubation time periods, the cells were harvested, washed twice in PBS, re-suspended in media supplemented with TMRE (200 nM), incubated at $37{ }^{\circ} \mathrm{C}$ for $20 \mathrm{~min}$ in the dark. Then, the media was replaced once with $100 \mu \mathrm{L}$ of PBS/0.2\% BSA, and then the fluorescence of TMRE was measured at an excitation wavelength of $549 \mathrm{~nm}$ by using a microplate reader (Perkin Elmer, Victor X5, Norwalk, CT, USA). The carbonyl cyanide-p-trifluoromethoxyphenylhydrazone (FCCP)-treated cells were used as a positive control.

\subsection{Fluorescent Assays for Measuring Caspase-3 Activity and Intracellular Reactive Oxygen Species (ROS) Generation}

Caspase activity assays in multi-well plate formats represent powerful tools for understanding experimental modulation of the apoptotic response. Caspase-3, $-8,-9$ activities were measured using the activity assay kit (Abcam, Cambridge, UK)) were purchased by Abcam according to the manufacturer's guidelines. Briefly, NCI-H460 and HepG2 cells were cultured into 96-well plates at a density of $2 \times 10^{4}$ cells/well. Then, old media were replaced by fresh ones having the AB2 compound at $\mathrm{IC}_{50}$ and $2 \times \mathrm{IC}_{50}$ concentrations, and cells were further incubated for $6 \mathrm{~h}$. Total of $100 \mu \mathrm{L}$ of Caspase 
reagent was added to each well. The fluorescence of each well was measured at excitation/emission $(\mathrm{Ex} / \mathrm{Em})=535 / 620 \mathrm{~nm}, \mathrm{Ex} / \mathrm{Em}=490 / 525 \mathrm{~nm}$, and $\mathrm{Ex} / \mathrm{Em}=370 / 450 \mathrm{~nm}$ for Caspase 3, Caspase 8, and Caspase 9 respectively for detecting fluorescence intensity using a plate-reading fluorescence reader (Perkin Elmer, Victor X5, Norwalk, CT, USA).

ROS generation was tested by using the ROS assay kit (ab113851, Abcam) according to the manufacturer's instructions. Briefly, the cells $\left(5 \times 10^{4}\right.$ cells/well) were cultured in 96-well plates. DCFH-DA was added to the cells at $37^{\circ} \mathrm{C}$ for $1 \mathrm{~h}$ in the dark. After incubation with AB2 compound at $\mathrm{IC}_{50}$ and $2 \times \mathrm{IC}_{50}$ concentrations for $0,4,8,16,20$, and $24 \mathrm{~h}$, cells were rinsed with PBS. Cells were measured on a fluorescent plate reader (Perkin Elmer, Victor X5, Norwalk, CT, USA), and mean \pm standard deviation was plotted for three replicates from each condition. Tert-butyl hydrogen peroxide (TBHP), which mimics ROS activity to oxidize DCFDA to fluorescent DCF, was used as positive control.

\subsection{Western Blot Analysis}

NCI-H460 and HepG2 cells were treated with $\mathrm{AB} 2$ compound at $\mathrm{IC}_{50}$ and $2 \times \mathrm{IC}_{50}$ concentrations and Camptothecin $(4 \mu \mathrm{g} / \mathrm{mL})$, then total protein was extracted using radioimmunoprecipitation assay buffer. Following by centrifuging at $14,000 \mathrm{rpm}$ for $20 \mathrm{~min}$ at $4{ }^{\circ} \mathrm{C}$, total proteins were obtained, measured, and subjected onto $12 \%$ sodium dodecyl sulfate-polyacrylamide gel electrophoresis (SDS-PAGE), separated and transferred onto a nitrocellulose membrane. Then, 5\% bovine serum albumin (BSA) was applied to block the membranes, followed by probing with anti-active caspase- 3 and anti- $\beta$-actin primary antibodies with gentle agitation overnight at $4{ }^{\circ} \mathrm{C}$. Afterward, the corresponding HRP-conjugated secondary antibody was applied and incubated for $1 \mathrm{~h}$ at room temperature after washing three times with TBST buffer (Tris-buffered saline, $0.1 \%$ Tween 20). The blots were visualized with enhanced chemiluminescence detection and quantified by densitometry using Image J version 1.47.

\subsection{Statistical Analysis}

The experiments were performed in triplicate. The data are expressed as mean \pm standard deviation. Significant differences between groups were determined by using Student $t$-test. $p$ value of less than 0.05 was considered significant.

\section{Results and Discussion}

\subsection{Brine Shrimp Lethality Test}

The brine shrimp assay is significantly associated with in vitro growth inhibition of human solid tumor cell lines which was demonstrated by the National Cancer Institute (NCI, USA) and it can show the value of this bioassay as a pre-screening tool for antitumor drug research [33]. This test is well correlated with antitumor activity (cytotoxicity) and can be used to monitor the activity of bioactive natural products [34]. As shown in Figure 1, the cytotoxicity demonstrates a relationship between the concentration of the samples and the degree of lethality, suggesting that the samples are biologically active. $\mathrm{LC}_{50}$ values were calculated using graph extrapolation as are shown in Table 1. Comparison to aqueous extract, the $\mathrm{LC}_{50}$ values for the ethanol extract at $24 \mathrm{~h}$ were $647.64 \mu \mathrm{g} / \mathrm{mL}$, has revealed that it more exhibited toxic expressions $\left(\mathrm{LC}_{50}\right.$ was less than $\left.1.0 \mathrm{mg} / \mathrm{mL}\right)$ against the brine shrimp [35]. The ethanol extract was then used to guide the fractionation process of the plant extract to isolate potential anti-cancer compounds. The chloroform fraction from ethanol extract was the most active among all fraction. Ethyl acetate fraction, $\mathrm{n}$-butanol fraction, and aqueous fraction gave $\mathrm{LC}_{50}>1000 \mu \mathrm{g} / \mathrm{mL}$, that are considered to be inactive. The variation in their results is possibly because of the different polarities of the solvents, the ethanol solvent is less polar than aqueous one and the phytochemicals of the ethanol extract contain specific molecules that have provided its cytotoxic activity against brine shrimp. As a result, the chloroform fraction of ethanol extract exhibited more 
toxicity against the brine shrimp at $205.58 \mu \mathrm{g} / \mathrm{mL}$ compared to that of other fractions, which was further used to isolate compounds.

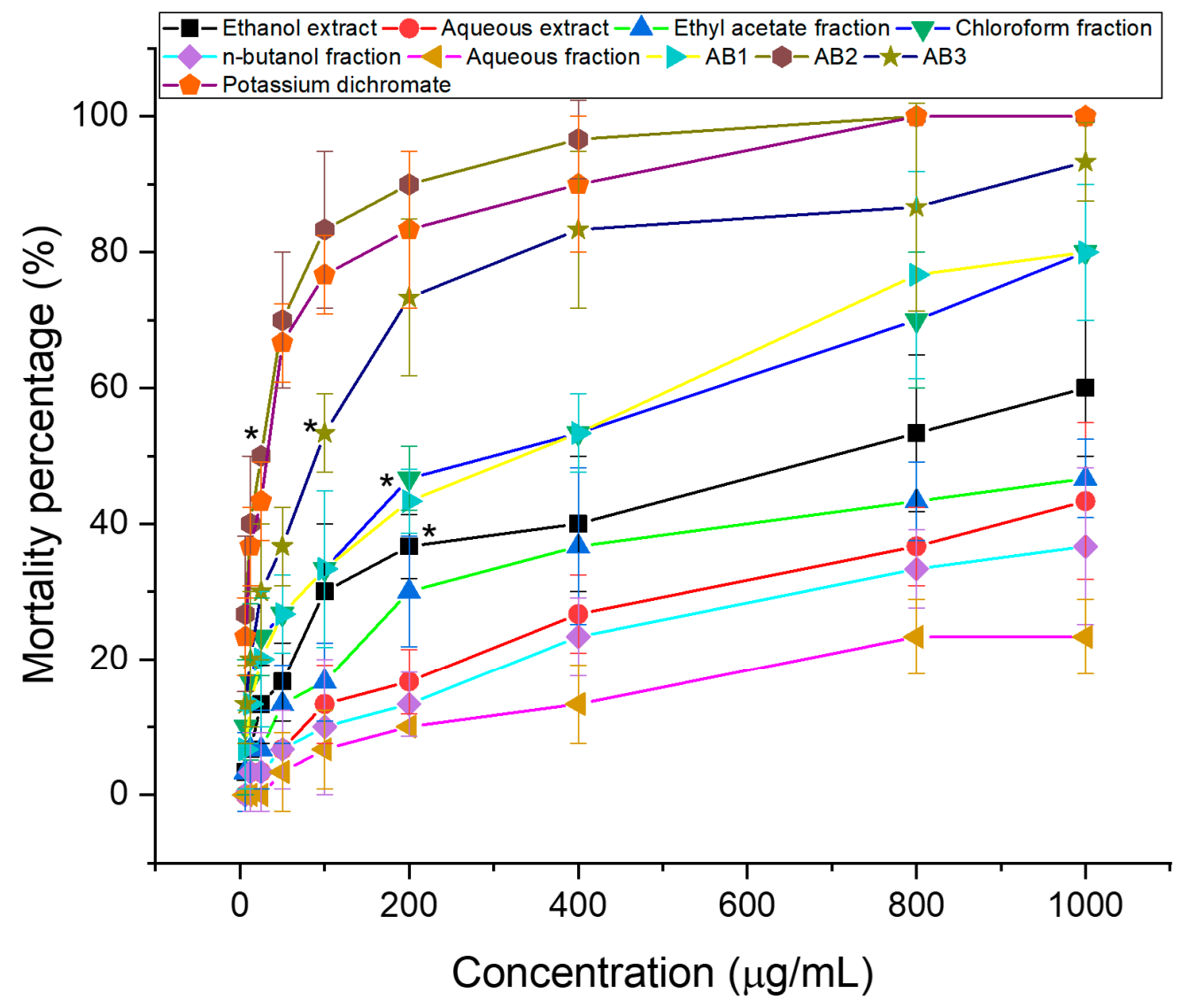

Figure 1. Brine shrimp lethality of extracts, fractions (A), and isolated compounds (B) at $24 \mathrm{~h}$, * mean significant difference $(p<0.05)$ compared to control.

Table 1. Brine shrimp toxicity expressed as $\mathrm{LC}_{50}$ value.

\begin{tabular}{|c|c|c|c|c|c|c|c|c|c|c|}
\hline \multirow{2}{*}{ Sample } & \multirow{2}{*}{$\begin{array}{c}\text { Ethanol } \\
\text { Extract }\end{array}$} & \multirow{2}{*}{$\begin{array}{c}\text { Aqueous } \\
\text { Extract }\end{array}$} & \multirow{2}{*}{$\begin{array}{l}\text { Chloroform } \\
\text { Fraction }\end{array}$} & \multirow{2}{*}{$\begin{array}{l}\text { Ethyl Acetate } \\
\text { Fraction }\end{array}$} & \multirow{2}{*}{$\begin{array}{l}n \text {-Butanol } \\
\text { Fraction }\end{array}$} & \multirow{2}{*}{$\begin{array}{l}\text { Aqueous } \\
\text { Fraction }\end{array}$} & \multicolumn{3}{|c|}{ Compound } & \multirow{2}{*}{$\begin{array}{l}\text { Potassium } \\
\text { Dichromate }\end{array}$} \\
\hline & & & & & & & AB1 & AB2 & $\mathrm{AB} 3$ & \\
\hline $\mathrm{LC}_{50}(\mu \mathrm{g} / \mathrm{mL})$ & 647.64 & $>1000$ & 205.58 & $>1000$ & $>1000$ & $>1000$ & 202.8 & 20.34 & 65.71 & 27.75 \\
\hline
\end{tabular}

\subsection{In Vitro Screening for Cytotoxic Activity of Extracts and Fractions}

The cytotoxic effect of extracts and fractions from A. bracteosum on the growth of NCI-H460 and HepG2 cancer cell lines were investigated by SRB assay. The cell inhibition activity of ethanol and aqueous extracts, chloroform, ethyl acetate, $n$-butanol, and aqueous fractions of $A$. bracteosum showed in Figure 2. The ethanol extract had high activities on the human non-small cell lung cancer carcinoma NCI-H460 (90.46 $\pm 1.61 \%)$ and HepG2 (69.23 $\pm 4.71 \%)$ cell lines but at the same concentration of $100 \mu \mathrm{g} / \mathrm{mL}$, aqueous had low activities $(<25 \%)$. The chloroform fraction from ethanol extract had the highest activity as compared to other fractions that percentage of cytotoxicity on cell line NCI-H460 and HepG2 was $89.29 \pm 0.63 \%$ and $76.40 \pm 3.62 \%$, respectively. As revealed in Figure 2, ethanol extract and chloroform fraction had significant cytotoxic activity against the cells in increasing dose concentration. The death of $50 \%$ of the tumor cells of ethanol extract on HepG2 and NCI-H460 was $39.15 \pm 0.61$ and $30.31 \pm 1.60 \mu \mathrm{g} / \mathrm{mL}$ while $\mathrm{IC}_{50}$ of chloroform fraction was $36.34 \pm 0.48$ and $38.35 \pm 2.04$, respectively. HepG2 cell was more sensitive to chloroform fraction than ethanol extract. The chloroform fraction was therefore further studied for the isolation of pure compounds. 

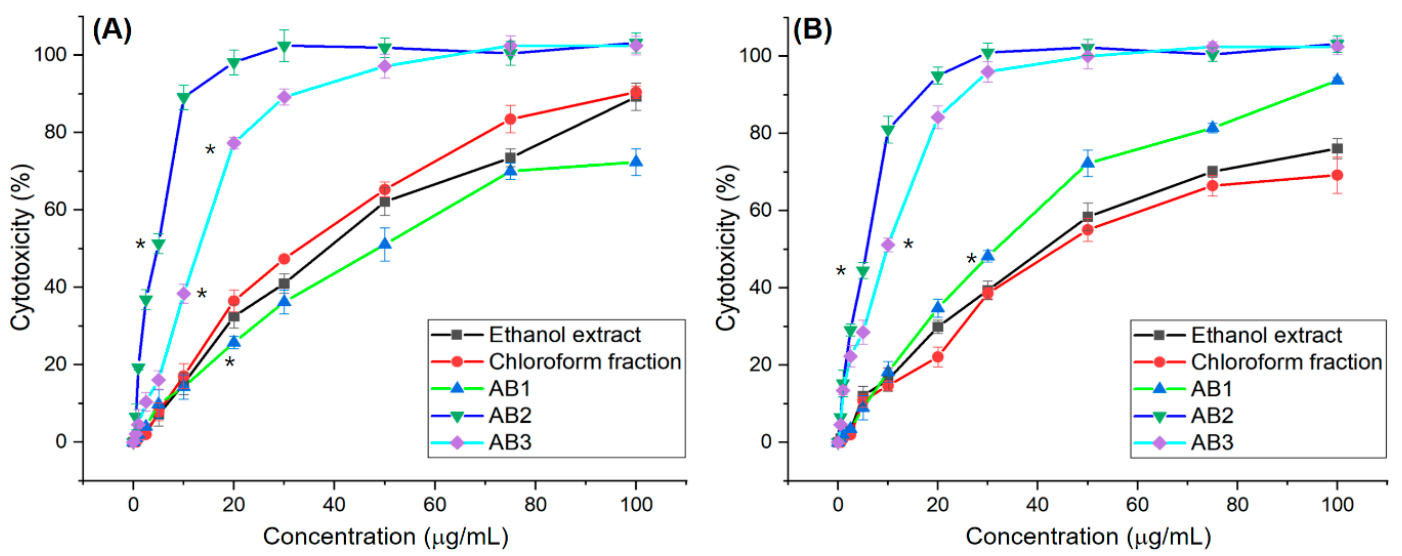

Figure 2. Cytotoxicity of extract, fraction, and compounds on NCI-H460 (A) and HepG2 (B) cells at different concentration, ${ }^{*}$ mean significant difference $(p<0.05)$ compared to control.

\subsection{Spectroscopic Data of Isolated Compounds}

The NMR spectra were measured on Bruker 500 Avance spectrometer (Karlsruhe, Germany) (500 MHz for ${ }^{1} \mathrm{H}$ NMR and $125 \mathrm{MHz}$ for ${ }^{13} \mathrm{C}$ NMR) spectrometers with tetramethylsilane (TMS) as internal standard. Chemical shifts are expressed in $\mathrm{ppm}$ with reference to the residual protonated solvent signals (DMSO- $d_{6}$ with $\delta_{\mathrm{H}} 2.50$ and $\delta_{\mathrm{C}} 39.52$, acetone- $d_{6}$ with $\delta_{\mathrm{H}} 2.05$ and $\delta_{\mathrm{C}} 29.840$ ). The EIMS were recorded on a HRESIMS Bruker MicroTOF (Billerica, MA, USA). TLC was carried out on precoated silica gel $60 \mathrm{~F}_{254}$ and spots were visualized by $\mathrm{UV}_{254 \mathrm{~nm}}, \mathrm{UV}_{365 \mathrm{~nm}}$ lamp (Spectroline, Westbury, NY, USA). Gravity column chromatography was performed with silica gel $60(0.040-0.063 \mathrm{~mm})$.

Compound AB1: Yellow amorphous powder. ESI-MS $m / z$ : $343.08[\mathrm{M}-\mathrm{H}]^{-} .{ }^{1} \mathrm{H}-\mathrm{NMR}(500 \mathrm{MHz}$, $\left.\mathrm{CD}_{3} \mathrm{OD}\right): \delta 7.85\left(1 \mathrm{H}, d, J=8.0 \mathrm{~Hz}, \mathrm{H}-2^{\prime} / \mathrm{H}^{-} 6^{\prime}\right), 6.94\left(1 \mathrm{H}, d^{\prime} J=8.0 \mathrm{~Hz}, \mathrm{H}-3^{\prime} / \mathrm{H}-5^{\prime}\right), 6.60$ (1H, s, H-3), 4.09 $\left(3 \mathrm{H}, \mathrm{s}, \mathrm{OCH}_{3}\right), 3,97\left(3 \mathrm{H}, \mathrm{s}, \mathrm{OCH}_{3}\right), 3.90\left(3 \mathrm{H}, \mathrm{s}, \mathrm{OCH}_{3}\right) .{ }^{13} \mathrm{C}-\mathrm{NMR}\left(125 \mathrm{MHz}\right.$, Acetone-d $\left.\mathrm{d}_{6}\right): \delta 183.1(\mathrm{C}-4)$, 152.0 (C-5), 164.3 (C-2), 161.3 (C-4' $), 149.0$ (C-8a), 136.0 (C-8), 133.0 (C-6), 128.5 (C-2' ), 128.5 (C-6'), 122.3 $\left(\mathrm{C}-1^{\prime}\right), 116.1\left(\mathrm{C}-3^{\prime}\right), 116.1\left(\mathrm{C}-5^{\prime}\right), 106.7(\mathrm{C}-4 \mathrm{a}), 102.8(\mathrm{C}-3), 61.4\left(-\mathrm{OCH}_{3}\right), 61.0\left(-\mathrm{OCH}_{3}\right), 60.1\left(-\mathrm{OCH}_{3}\right)$. These spectroscopic data were consistent with those of xanthomicrol [16] (Figure 3). 1D and 2D NMR spectra of AB1 were also provided in Supplementary Materials file.

Compound AB2: Yellow amorphous powder. ESI-MS $m / z: 373.10[\mathrm{M}-\mathrm{H}]^{-} .{ }^{1} \mathrm{H}-\mathrm{NMR}(500 \mathrm{MHz}$, Acetone- $\left.\mathrm{d}_{6}\right): \delta 7.66\left(1 \mathrm{H}, d d, J=1.5,8.0 \mathrm{~Hz}, \mathrm{H}-2^{\prime}\right), 7.65\left(1 \mathrm{H}, b r s, \mathrm{H}-6^{\prime}\right), 7.04\left(1 \mathrm{H}, d, J=8.0 \mathrm{~Hz}, \mathrm{H}-3^{\prime}\right), 6.75$ $(1 \mathrm{H}, \mathrm{s}, \mathrm{H}-3), 4.09\left(3 \mathrm{H}, \mathrm{s}, \mathrm{OCH}_{3}\right), 3.97\left(3 \mathrm{H}, \mathrm{s}, \mathrm{OCH}_{3}\right), 3.90\left(3 \mathrm{H}, \mathrm{s}, \mathrm{OCH}_{3}\right), 3.88\left(3 \mathrm{H}, \mathrm{s}, \mathrm{OCH}_{3}\right) .{ }^{13} \mathrm{C}-\mathrm{NMR}$ (125 MHz, Acetone- $\mathrm{d}_{6}$ ): 183.0 (C-4), 164.4 (C-2), 152.0 (C-7), 151.0 (C-4'), 148.0 (C-8a), 145.7 (C-5'), 136.0 (C-8), 133.0 (C-6), 122.4 (C-1'), 120.6 (C-2'), 115.6 (C-3'), 109.6 (C-6') 106.7 (C-4a), 103.0 (C-3), $61.4\left(-\mathrm{OCH}_{3}\right), 61.0\left(-\mathrm{OCH}_{3}\right), 60.1\left(-\mathrm{OCH}_{3}\right), 55.6\left(-\mathrm{OCH}_{3}\right)$. These results were consistent with those of 5,4'-dihydroxy-6,7,8,3'-tetramethoxyflavone [24,36,37] (Figure 3). 1D and 2D NMR spectra of AB2 were also provided in Supporting Materials file. NMR data assignments were completed through detailed analysis of HMBC experimental data (Figure 4).<smiles>COc1cc(-c2cc(=O)c3c(O)c(OC)c(OC)c(OC)c3o2)ccc1O</smiles>

AB1
AB2<smiles>C[C@H]1CCC2(C(=O)O)CC[C@]3(C)C(=CCC4[C@@]5(C)CC[C@H](O)C(C)(C)C5CC[C@]43C)C2[C@@H]1C</smiles>

AB3

Figure 3. Chemical structures of $A B 1, A B 2$ and $A B 3$. 
Compound AB3: White amorphous powder. ESI-MS m/z: $455.37[\mathrm{M}-\mathrm{H}]^{-1} \mathrm{H}-\mathrm{NMR}(500 \mathrm{MHz}$, DMSO-d $\left.\mathrm{d}_{6}\right): \delta 0.66 \mathrm{ppm}(1 \mathrm{H}, \mathrm{d}, J=11.3 \mathrm{~Hz}, \mathrm{H}-5), 0.77 \mathrm{ppm}\left(3 \mathrm{H}, \mathrm{s}, 24-\mathrm{CH}_{3}\right), 0.81 \mathrm{ppm}\left(3 \mathrm{H}, \mathrm{s}, 26-\mathrm{CH}_{3}\right)$, $0.85\left(3 \mathrm{H}, \mathrm{d}, J=6.4 \mathrm{~Hz}, 29-\mathrm{CH}_{3}\right), 0.90 \mathrm{ppm}\left(3 \mathrm{H}, \mathrm{d}, J=4.2 \mathrm{~Hz}, 25-\mathrm{CH}_{3}\right), 0.92\left(3 \mathrm{H}, \mathrm{s}, 30-\mathrm{CH}_{3}\right), 0.94$ $\left(3 \mathrm{H}, \mathrm{d}, J=6.2 \mathrm{~Hz}, 23-\mathrm{CH}_{3}\right), 1.08\left(3 \mathrm{H}, \mathrm{s}, 27-\mathrm{CH}_{3}\right), 1.99 \mathrm{ppm}(1 \mathrm{H}, \mathrm{dd}, J=4.1,13.4 \mathrm{~Hz}, \mathrm{H}-6), 2.11 \mathrm{ppm}$ $(1 \mathrm{H}, \mathrm{d}, J=13.1 \mathrm{~Hz}, \mathrm{H}-18), 3.00 \mathrm{ppm}(1 \mathrm{H}, \mathrm{dd}, J=6.8,9.9 \mathrm{~Hz}, \mathrm{H}-3), 5.14 \mathrm{ppm}(1 \mathrm{H}, \mathrm{dd}, J=3.4,6.8 \mathrm{~Hz}$, H-12). ${ }^{13} \mathrm{C}-\mathrm{NMR}\left(125 \mathrm{MHz}, \mathrm{DMSO}-\mathrm{d}_{6}\right): \delta 178.0$ (C-28), 138.4 (C-13), 124.4 (C-12), 76.9 (C-3), 54.8 (C-5), 52.4 (C-18), 47.0 (C-17), 46.8 (C-9), 41.6 (C-14), 39.1 (C-8), 38.5 (C-4), 38.5 (C-19), 38.4 (C-20), 38.3 (C-1), 36.5 (C-10), 36.3 (C-22), 27.0 (C-2), 18.0 (C-6), 32.7 (C-7), 30.2 (C-21), 28.3 (C-23), 27.6 (C-15), 23.8 (C-16), 23.3 (C-27), 22.9 (C-11), 21.1 (C-30), 17.0 (C-26), 16.9 (C-29), 16.1 (C-24), 15.2 (C-25). This compound was identified as ursolic acid [19] (Figure 3) and also demonstrated to be effective for the treatment of a wide spectrum of diseases [38] including antioxidant [39], anti-inflammatory [40], antibacterial [41], antiviral [41], antifungal [41], antipyretic [38], anticancer [42], antitumor [42], antiwrinkle [43], anti-hypertension [44], and hepatoprotective activities [45].

Indeed, $\mathrm{LC}_{50}$ values of AB1, AB2, and AB3 were observed to be $202.80,20.34$, and $65.71 \mu \mathrm{g} / \mathrm{mL}$, respectively, whereas this figure was revealed for the positive control (potassium dichromate) at $24 \mathrm{~h}$ was $27.75 \mu \mathrm{g} / \mathrm{mL}$, indicating these toxic compounds expressions well against the brine shrimp. Hence, further investigation of these compounds to their toxic expressions on cancer cell lines should be pursued.

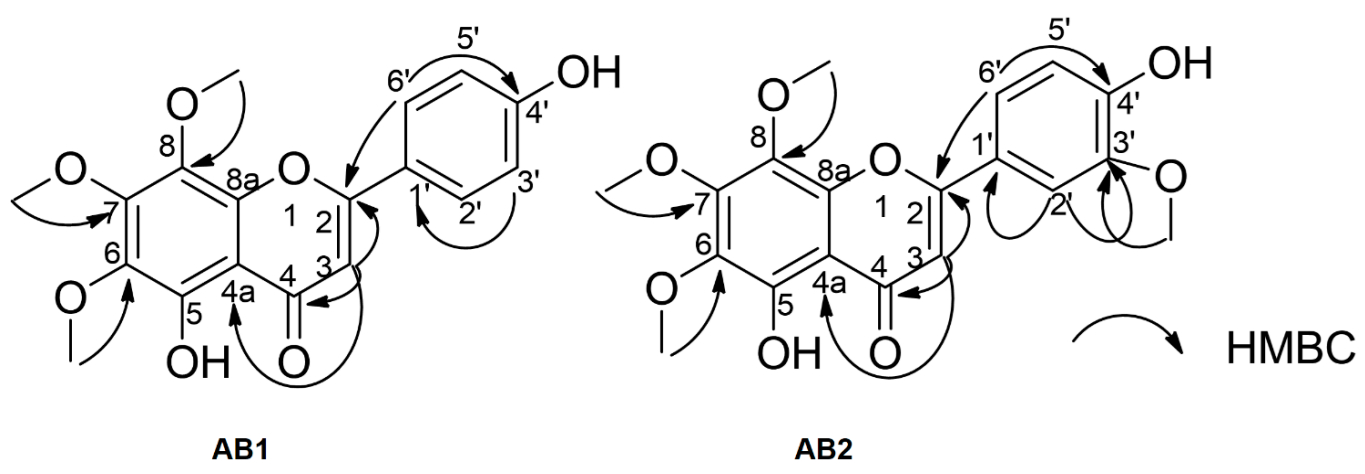

Figure 4. Selected heteronuclear multiple bond correlation (HMBC) correlations from AB1 and AB2.

\subsection{Bioactivity of Isolated Compounds}

\subsubsection{Antioxidant Activity Assessments}

ABTS+ and 2,2-diphenyl-1-picrylhydrazile (DPPH) assays are widely used to evaluate compounds' ability to determine their antioxidant potential. The free radical inhibition of three compounds and reference antioxidant (ascorbic acid) at concentrations was shown in Figure 5A, the DPPH scavenging activity of $\mathrm{AB} 1, \mathrm{AB} 2$, and $\mathrm{AB} 3$ increased progressively with the concentration. $\mathrm{AB} 2$ was the most active radical scavenging which showed an $\mathrm{IC}_{50}$ of $4.04 \mu \mathrm{g} / \mathrm{mL}$ and was 1.37 fold lower than that of ascorbic acid $\left(\mathrm{IC}_{50}=2.95 \mu \mathrm{g} / \mathrm{mL}\right)$, followed by $\mathrm{AB} 1$ and $\mathrm{AB} 3$ with the $\mathrm{IC}_{50}$ values were 4.45 and $11.93 \mu \mathrm{g} / \mathrm{mL}$, respectively $(p<0.05)$.

The ABTS+ assay is additionally an important method for quantifying radical scavenging activity, which can provide comparable results to those obtained in the DPPH assay. As indicated in Figure 5B, three compounds significantly exhibited ABTS-free radical scavenging activity. Three compounds had an antioxidant activity comparable to that of ascorbic acid. AB2 was a strong active radical scavenger, showing an $\mathrm{IC}_{50}$ of $6.53 \pm 0.16 \mu \mathrm{g} / \mathrm{mL}$ and 1.24 times lower than that of ascorbic acid, followed by AB1 and $\mathrm{AB} 3$ with the $\mathrm{IC}_{50}$ values of 7.09 and $11.41 \mu \mathrm{g} / \mathrm{mL}$, respectively $(p<0.05)$. In both the assays, AB2 exhibited the highest ABTS and DPPH radical scavenging activities. The correlation between DPPH and ABTS methods used to measure the antioxidant activity of the compounds has been examined. The DPPH radical activity also showed a strong correlation with ABTS $\left(R^{2}=97.56 \%\right)$. 
Reactive oxygen species (ROS) cause a variety of cancers in humans [46]. ROS can damage macro biomolecules such as proteins, lipids, and DNA and reduce the DNA repair capability that can result in normal cells being transformed into cancer cells by mutating key genes [47]. Research on potent antioxidants or scavengers thus contributes to the prevention of cancer. Some previous studies have shown that phenols and flavonoids have strong antioxidants and are effective anticancer agents through anti-angiogenic and apoptosis activities [48,49]. In fact, in this study, A2, a flavonoid showed good antioxidant and cytotoxic effects.
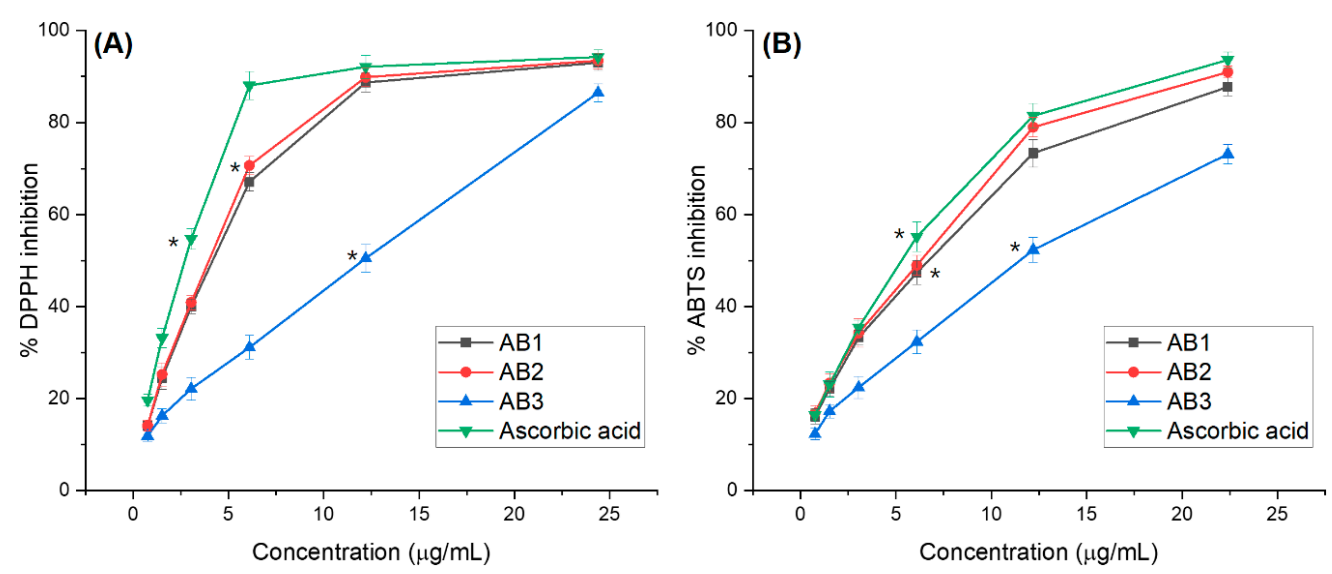

Figure 5. (A) 2,2-diphenyl-1-picrylhydrazyl (DPPH) and (B) ABTS+ radical scavenging activities. AB1: Xanthomicrol, AB2: 5,4'-dihydroxy-6,7,8,3'-tetramethoxyflavone, AB3: Ursolic acid, ABTS: 2,2'-azino-bis(3-ethylbenzothiazoline-6-sulfonic acid Values are given as mean \pm standard deviation, * mean significant difference $(p<0.05)$ compared to control.

\subsubsection{Brine Shrimp Bioassay}

$A B 1, A B 2$, and $A B 3$ were identified as confirmed by their cytotoxic effects through brine shrimp bioassay (Figure 1). $\mathrm{LC}_{50}$ values of $\mathrm{AB} 1, \mathrm{AB} 2$, and $\mathrm{AB} 3$ were $202.80,20.34$, and $65.71 \mu \mathrm{g} / \mathrm{mL}$, respectively, which demonstrated (possessed) significant activity against the brine shrimp. The positive control $\mathrm{LC}_{50}$ values were $27.75 \mu \mathrm{g} / \mathrm{mL}$, indicating toxic expressions against the brine shrimp. AB2 had a higher $\mathrm{LC}_{50}$ than the positive control, highlighting the cytotoxic effect.

\subsection{In Vitro Screening for Cytotoxic Activity of Compounds}

The cell inhibition activity of compounds including AB1, AB2, and AB3 is presented in Figure 2. Calculation of the dose of $\mathrm{AB} 1, \mathrm{AB} 2$, and $\mathrm{AB} 3$ revealed the following $\mathrm{IC}_{50}$ values for NCI-H460 and HepG2 cells: $32.5 \pm 0.41$ and $49.2 \pm 0.81 \mu \mathrm{g} / \mathrm{mL} ; 4.57 \pm 0.32$ and $5.67 \pm 0.09 \mu \mathrm{g} / \mathrm{mL} ; 13.05 \pm 0.55$ and $10.00 \pm 0.16 \mu \mathrm{g} / \mathrm{mL}$, respectively. According to the criteria of the National Cancer Institute and Geran protocol, extracts with $\mathrm{IC}_{50} \leq 20 \mu \mathrm{g} / \mathrm{mL}=$ highly cytotoxic, $\mathrm{IC}_{50}$ ranged between 21 and $200 \mu \mathrm{g} / \mathrm{mL}=$ moderately cytotoxic, $\mathrm{IC}_{50}$ ranged between 201 and $500 \mu \mathrm{g} / \mathrm{mL}=$ weakly cytotoxic, and $\mathrm{IC}_{50}>501 \mu \mathrm{g} / \mathrm{mL}=$ no cytotoxicity [50-52]. These results clearly reveal that test of the ethanol extract, chloroform fraction and AB1 on the two cell lines revealed less cytotoxicity. Interestingly, the compound AB2 (5,4'-dihydroxy-6,7,8,3'-tetramethoxyflavone) and AB3 (ursolic acid) have excellent cytotoxic activity for two types of cancer cells, in which the highest percent anticancer activity was observed in $\mathrm{AB} 2$, followed by the ursolic acid with the lower percent inhibition at the same concentration. These compounds $\mathrm{AB} 2$ and $\mathrm{AB} 3$ are greatly considered to have in vitro cytotoxic activity with an $\mathrm{IC}_{50}$ value $\leq 10 \mu \mathrm{g} / \mathrm{mL}$ for the cells.

Among the isolated compounds, ursolic acid (AB3) has been well documented as a naturally synthesized pentacyclic triterpenoid, widely distributed in different fruits and vegetables [53-55] and has been known as an excellent anticancer agent $[8,11]$ by inducing apoptosis in several human cancer cells [56,57]. Remarkably, the compound 5,4'-dihydroxy-6,7,8,3'-tetramethoxyflavone (AB2) was 
isolated for the first time in the A. bracteosum. Further research investigating the cellular and molecular mechanisms underlying the effects of 5,4'-dihydroxy-6,7,8,3'-tetramethoxyflavone is required for the development of new therapeutic agents.

\subsection{DNA Fragmentation and Apoptosis Induced by 5,4'-Dihydroxy-6,7,8,3'-Tetramethoxyflavone}

To seek the mechanism of cell death mediated by 5,4'-dihydroxy-6,7,8,3'-tetramethoxyflavone (AB2), we first performed DNA fragmentation assay, which is characteristic for apoptosis. We treated the cells with 5,4'-dihydroxy-6,7,8,3'-tetramethoxyflavone at its $\mathrm{IC}_{50}$ for $24 \mathrm{~h}$, and DNA was then isolated and separated by agarose gel electrophoresis. As shown in Figure 6A, the HepG2 cells treated with $5 \mu \mathrm{g} / \mathrm{mL}$ of AB2 showed significant fragmentation after $24 \mathrm{~h}$ of AB2 treatment compared to the treatment of camptothecin at $4 \mu \mathrm{g} / \mathrm{mL}$. Also, an oligo nucleosomal ladder of fragmented DNA was obtained after the treatment in NCI-H460 cells (Figure 6B), whereas no DNA fragments were observed when untreated in both cells. These data strongly suggest that 5,4'-dihydroxy-6,7,8,3'-tetramethoxyflavone is a potent inducer of apoptosis in the cells.

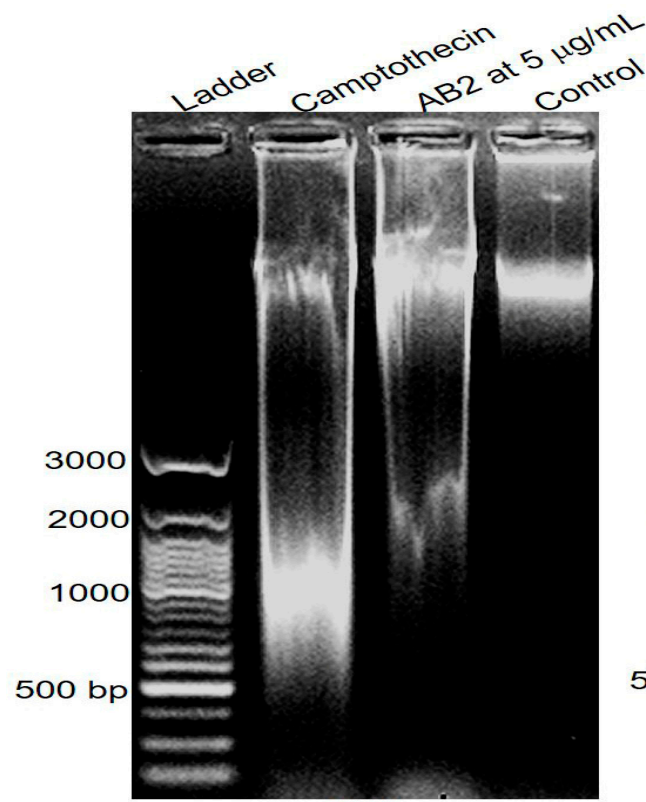

(A)

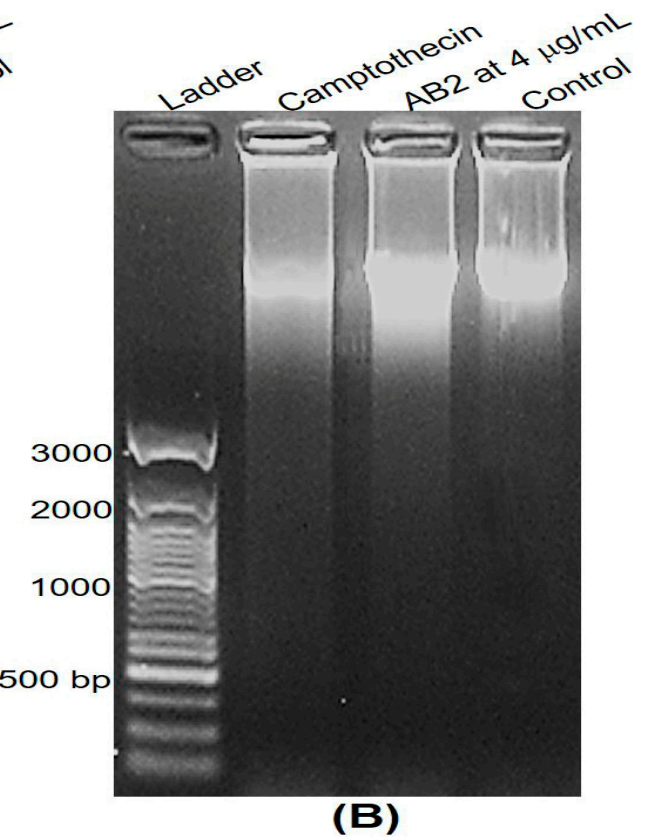

(B)

Figure 6. Apoptosis induced by 5,4'-dihydroxy-6,7,8,3'-tetramethoxyflavone at its $\mathrm{IC}_{50}$ in HepG2 (A) and NCI-H460 (B) cells.

In addition, to further evaluate the potential mechanism of the compound 5,4'-dihydroxy6,7,8,3'-tetramethoxyflavone-induced inhibition of human lung and hepatocyte carcinoma cell proliferation, we continuously examined the mode of cell death on NCI-H460 and HepG2 cells Annexin V-FITC/propidium iodide (PI) staining caused by the compound. Meanwhile, PI was used to only stain necrotic cells because of its increased membrane permeability and eventual propidium uptake in the cells [58]. In this study, Figure 7 reveals total apoptosis percent from treated and untreated NCI-H460 and HepG2 cells which were determined through the flow-cytometric outcomes. As shown in Figure 7A, NCI-H460 cells were treated with AB2 at $4 \mu \mathrm{g} / \mathrm{mL}\left(\sim \mathrm{IC}_{50}\right)$ caused the lowest apoptosis $(42.1 \%)$ within $24 \mathrm{~h}$ of treatment, relative to the control cells $(\sim 5.1 \%)$, whereas the figures seemed to be similar for HepG2 cells (Figure 7B). Remarkably, AB2 exposure, $\left(8 \mu \mathrm{g} / \mathrm{mL} 2 \times \mathrm{IC}_{50}\right)$ and $\left(10 \mu \mathrm{g} / \mathrm{mL} 2 \times \mathrm{IC}_{50}\right)$, caused a significant increase in apoptosis and necrosis in both NCI-H460 and HepG2 cells, which were about 2.3-fold and 2.2-fold higher than that of at $\mathrm{IC}_{50}$ doses, respectively. With respect to the cytotoxicity effect, AB2 could lead to DNA damage, apoptosis in terms of the number of cell death events, because it contains a number ROS radicals [59]. 


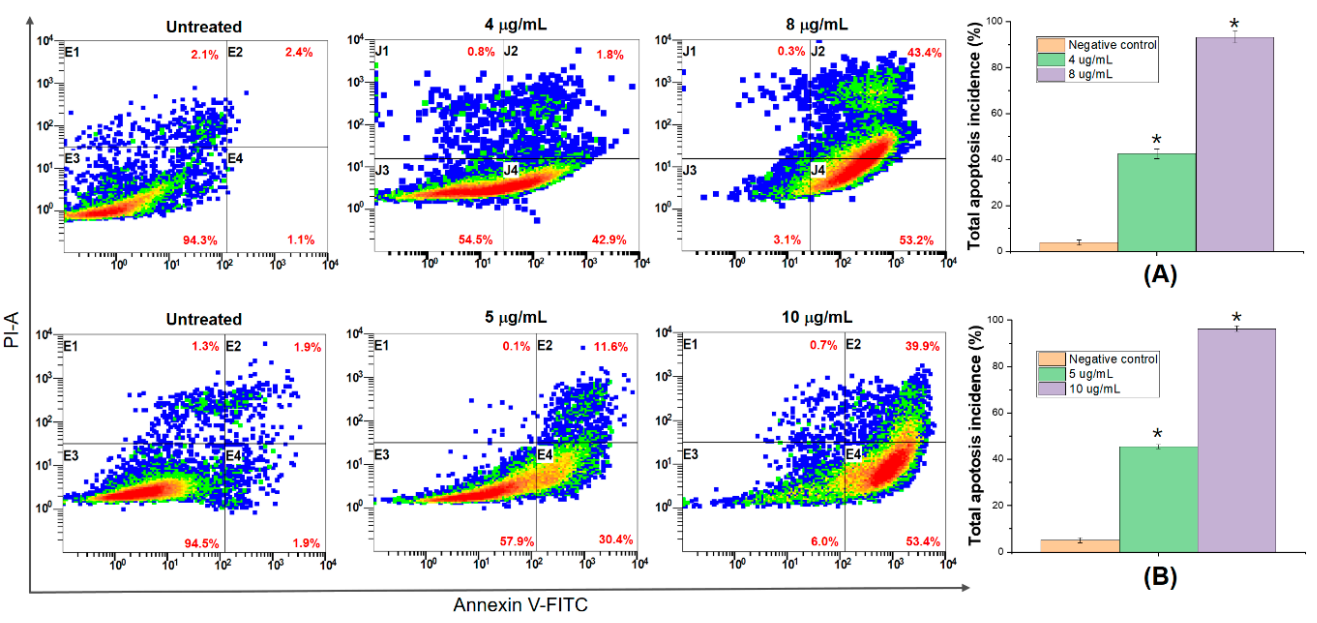

Figure 7. The total percentages of AB2-induced apoptosis in NCI-H460 (A) and HepG2 (B) cells, * mean significant difference $(p<0.05)$ compared to control.

3.7. 5,4'-Dihydroxy-6,7,8,3'-Tetramethoxyflavone Triggers Apoptosis Sensitivity by ROS-Caspase-3 Mediated in Human Hepatocyte Carcinoma Cell

The disruption of mitochondrial membrane potential may result in apoptosis [60]; thus, we next evaluated, by TMRE assay, whether AB2 mediated the cells. FCCP treatment as in the positive control group caused a significant loss of mitochondrial membrane potentials in comparison to the control group $(p<0.05)$. Interestingly, the same figure was observed following the treatment $\left(\mathrm{IC}_{50}\right.$ and $\left.2 \times \mathrm{IC}_{50}\right)$ with $\mathrm{AB} 2(p<0.05)$, strongly revealing the presence of $\mathrm{AB} 2$-mediated perturbation of mitochondrial metabolic activity in NCI-H460 and HepG2 cells (Figure 8A).

ROS is known to play a dual role; either that may be harmful depending on their accumulation levels, generally contributing to cell death either by apoptosis or necrosis at the levels beyond the cellular antioxidant defense mechanisms [60-62]. Generally, higher mitochondrial membrane potential results in greater adenosine triphosphate (ATP) production and greater ROS production [63]. Thus, the intracellular ROS levels were determined by measuring the intensity of a highly fluorescent derivative $2^{\prime}, 7^{\prime}$-dichlorofluorescein (DCF) which is generated from an externally applied non-fluorescent substance, DCFH-DA by the cellular redox reactions. As shown in Figure 8B-C, AB2 dose-dependently increased the ratio of green fluorescence in NCI-H460 and HepG2 cells suggesting that AB2 excitants production of intracellular ROS in the cells compared to the control group, camptothecin $(p<0.05)$. The antioxidant from AB2 succeeded in inverting the cytotoxic effect of both cells. These figures strongly indicate that $\mathrm{AB} 2$ treatment in a concentration- and time- dependent manner led to ROS-dependent and independent cell death in human lung and hepatocellular carcinoma cells.

During apoptosis, the permeabilization of the mitochondrial outer membrane caused the release of cytochrome c [64], which induces caspase activation to orchestrate the death of the cell due to its loss of mitochondrial function and generation of ROS [65]. Overproduction of ROS could be associated with cell homeostasis imbalance, mitochondrial damage, and apoptosis [60,66]. Activation of apoptosis pathways through the mitochondrial pathway could be is one of the key steps in apoptosis $[67,68]$, which is generally related to recruitment of caspase family proteins including caspase-8 and/or caspase-3 [69]. Thus, the caspase activities pathway is checked to evaluate whether or not AB2 affects the induction of apoptosis. As shown in Figure 8D-E, the cells treated with AB2 resulted in increased percentage of caspase-3, -8, -9 activities compared to the negative control. However, AB2 did not affect much the caspase- 8 and -9 activities and resulted in slightly increased expression in the cells in comparison to caspase- 3 outcomes. Indeed, there was a significantly increased apoptotic cell frequency in the cells by $\sim 4.5$ and $\sim 7.2$-fold by treatment with 5,4'-dihydroxy-6,7,8,3'-tetramethoxyflavone at $\mathrm{IC}_{50}$ and $2 \times \mathrm{IC}_{50}$ respectively, as compared with the untreated groups, suggesting that $\mathrm{AB} 2$ stimulates caspase- 3 in human lung and hepatocellular carcinoma cells. 

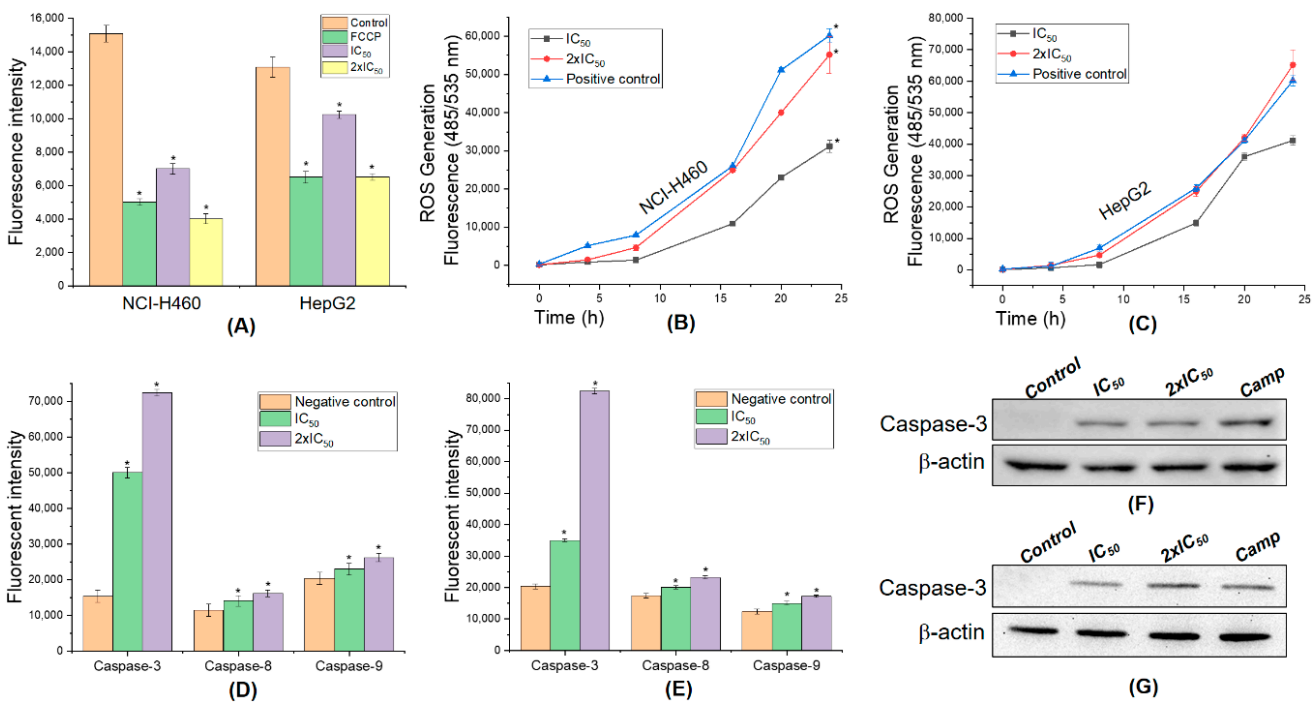

Figure 8. Potential mechanism of action of 5,4'-dihydroxy-6,7,8,3'-tetramethoxyflavone on human liver and lung cancer cells. (A) Mitochondrial membrane potential; ROS production in NCI-H460 (B) and HepG2 (C) cells by DCFH-DA essay. The caspase activity in the NCI-H460 (D) and HepG2 (E) cells treated with AB2. Expression of active caspase-3 protein on NCI-H460 (F) and HepG2 (G) cells was confirmed by Western blot analysis, ${ }^{*}$ mean significant difference $(p<0.05)$ compared to control.

Finally, the expression level of apoptosis-related active protein (cleaved) caspase-3 was confirmed by Western blot assay. The expression of active caspase- 3 protein was clearly revealed by only $\mathrm{IC}_{50}$ and $2 \mathrm{xIC}_{50}$ of $\mathrm{AB} 2$ treatment compared to the positive control group (Figure $8 \mathrm{~F}-\mathrm{G}$ ). This figure is consistent in comparison with the significantly increased levels of active caspase- 3 from fluorescence assay. Our results revealed that the role of 5,4'-dihydroxy-6,7,8,3'-tetramethoxyflavone-induced apoptosis in both human lung and hepatocellular carcinoma cells was dependent on the activation caspase-3.

These findings revealed that these extracts and compounds are very potent antioxidants because of their radical scavenging capacity and their capacity to stimulate ROS-mediated mitochondrial pathway because of the activation of caspase-3. The interactions may result from new anticancer molecules in which antioxidants can also be enhanced to eliminate cancer cells through the apoptosis pathway, where antioxidants from medicinal plants have shown a great cytotoxic potential [70,71]. This has been demonstrated through caspase-independent cell death from H. speciosa [72] and J. Decurrens [73], whereas others such as C. adamantium [74], S. velutina [72], and S. Adstringens [75] destroyed malignant haematologic cells or melanoma cells through apoptosis. The search for new antioxidants containing toxicity profile is desirable, and the A. bracteosum (Bonati) demonstrated here may represent interesting targets for this purpose.

\section{Conclusions}

The current investigation strongly demonstrate that $A$. bracteosum could significantly inhibit the growth of human NCI-H460 and HepG2 cells as well as the brine shrimp. Importantly, a new compound, 5,4'-dihydroxy-6,7,8,3'-tetramethoxyflavone was investigated, and demonstrated to be probably by ROS-mediated mitochondrial pathway, followed by activated caspase-3, associated with the apoptosis cells death. These results suggest that $A$. bracteosum is a promising source of useful natural products and the new compound offers opportunities to develop novel anticancer drug after its full apoptosis activity has been clinically addressed.

Supplementary Materials: The following are available online at http://www.mdpi.com/1420-3049/25/12/2912/s1. Figure S1: ESI mass spectrum of AB1. Figure S2: The ${ }^{1} \mathrm{H}$ NMR spectrum of AB1 in methanol- $d_{4}$. Figure S3: The ${ }^{13} \mathrm{C}$ NMR spectrum of AB1 in acetone- $d_{6}$. Figure S4: HSQC spectrum of AB1 in acetone- $d_{6}$. Figure S5: HMBC spectrum of AB1 in Acetone- $d_{6}$. Figure S6: EI mass spectrum of AB2. Figure S7: The ${ }^{1} \mathrm{H}$ NMR spectrum of AB2 
in acetone- $d_{6}$. Figure S8: The ${ }^{13} \mathrm{C}$ NMR spectrum of AB2 in acetone- $d_{6}$. Figure S9: HSQC spectrum of AB2 in acetone- $d_{6}$. Figure S10: HMBC spectrum of AB2 in Acetone- $d_{6}$. Figure S11: The ${ }^{1} \mathrm{H}$ NMR spectrum of AB3 in DMSO- $d_{6}$. Figure S12: The ${ }^{13}$ C NMR spectrum of AB3 in DMSO- $d_{6}$. Table S1: NMR spectral data of AB1 and AB2 compounds. Table S2: Compare AB3 compound spectral data and reference.

Author Contributions: N.H.N., Q.T.H.T., Q.T.P., T.N.H.L., V.T.P., T.-H.D., and V.G.V. conceived, designed, performed the experiments; Q.T.T.H., Q.T.P., T.N.H.L., V.T.P., and T.H.D. performed compound isolation and bioactivity essays; N.H.N. substantive supervision and project administration; N.H.N. and V.G.V. wrote and revised the whole manuscript. All authors have read and agreed to the published version of the manuscript.

Funding: This research received no external funding.

Conflicts of Interest: No conflict of interest associated with this work.

\section{References}

1. Siegel, R.L.; Miller, K.D.; Jemal, A. Cancer statistics, 2020. CA Cancer J. Clin. 2020, 70, 7-30. [CrossRef]

2. Pucci, C.; Martinelli, C.; Ciofani, G. Innovative approaches for cancer treatment: Current perspectives and new challenges. Ecancermedicalscience 2019, 13, 961. [CrossRef]

3. Chikara, S.; Nagaprashantha, L.D.; Singhal, J.; Horne, D.; Awasthi, S.; Singhal, S.S. Oxidative stress and dietary phytochemicals: Role in cancer chemoprevention and treatment. Cancer Lett. 2018, 413, 122-134. [CrossRef]

4. Singh, S.; Sharma, B.; Kanwar, S.S.; Kumar, A. Lead Phytochemicals for Anticancer Drug Development. Front. Plant Sci. 2016, 7, 8973. [CrossRef]

5. Sak, K. Chemotherapy and Dietary Phytochemical Agents. Chemother. Res. Pract. 2012, 2012, 1-11. [CrossRef]

6. Baskar, R.; Dai, J.; Wenlong, N.; Yeo, R.; Yeoh, K.-W. Biological response of cancer cells to radiation treatment. Front. Mol. Biosci. 2014, 1, 24. [CrossRef]

7. Wood, D.M.; Athwal, S.; Panahloo, A. The advantages and disadvantages of a 'herbal' medicine in a patient with diabetes mellitus: A case report. Diabet. Med. 2004, 21, 625-627. [CrossRef]

8. Yin, S.-Y.; Wei, W.-C.; Jian, F.-Y.; Yang, N.-S. Therapeutic applications of herbal medicines for cancer patients. Evid. Based Complement. Altern. Med. 2013, 2013, 302426. [CrossRef]

9. Nguyen, N.H.; Nguyen, T.T.; Ma, P.C.; Ta, Q.T.H.; Duong, T.-H.; Van Giau, V. Potential Antimicrobial and Anticancer Activities of an Ethanol Extract from Bouea macrophylla. Molecules 2020, 25, 1996. [CrossRef]

10. Duong, T.H.; Beniddir, M.A.; Trung, N.T.; Phan, C.D.; Vo, V.G.; Nguyen, V.K.; Le, Q.L.; Nguyen, H.D.; Le Pogam, P. Atypical Lindenane-Type Sesquiterpenes from Lindera myrrha. Molecules 2020, 25, 1830. [CrossRef]

11. Iqbal, J.; Abbasi, B.A.; Ahmad, R.; Mahmood, T.; Kanwal, S.; Ali, B.; Khalil, A.T.; Shah, A.; Alam, M.M.; Badshah, H. Ursolic acid a promising candidate in the therapeutics of breast cancer: Current status and future implications. Biomed. Pharmacother. 2018, 108, 752-756. [CrossRef]

12. Agarwal, G.; Carcache, P.J.B.; Addo, E.M.; Kinghorn, A.D. Current status and contemporary approaches to the discovery of antitumor agents from higher plants. Biotechnol. Adv. 2020, 38, 107337. [CrossRef]

13. Iqbal, J.; Abbasi, B.H.; Batool, R.; Mahmood, T.; Ali, B.; Khalil, A.T.; Kanwal, S.; Shah, A.; Ahmad, R. Potential phytocompounds for developing breast cancer therapeutics: Nature's healing touch. Eur. J. Pharmacol. 2018, 827, 125-148. [CrossRef]

14. Avtanski, D.; Poretsky, L. Phyto-polyphenols as potential inhibitors of breast cancer metastasis. Mol. Med. 2018, 24, 29. [CrossRef]

15. Power, F.B.; Salway, A.H. Chemical Examination of Micromeria Chamissonis. J. Am. Chem. Soc. 1908, 30, 251-265. [CrossRef]

16. Jahaniani, F.; Ebrahimi, S.A.; Rahbar-Roshandel, N.; Mahmoudian, M. Xanthomicrol is the main cytotoxic component of Dracocephalum kotschyii and a potential anti-cancer agent. Phytochemistry 2005, 66, 1581-1592. [CrossRef]

17. Fattahi, M.; Cusido, R.M.; Khojasteh, A.; Bonfill, M.; Palazon, J. Xanthomicrol: A comprehensive review of its chemistry, distribution, biosynthesis and pharmacological activity. Mini-Rev. Med. Chem. 2014, 14, 725-733. [CrossRef] [PubMed]

18. Abbaszadeh, H.; Ebrahimi, S.A.; Akhavan, M.M. Antiangiogenic Activity of Xanthomicrol and Calycopterin, Two Polymethoxylated Hydroxyflavones in Both In Vitro and Ex Vivo Models. Phytother. Res. 2014, 28, 1661-1670. [CrossRef] 
19. Harmand, P.-O.; Delage, C.; Simon, A.; Duval, R.E. Ursolic acid induces apoptosis through mitochondrial intrinsic pathway and caspase-3 activation in M4Beu melanoma cells. Int. J. Cancer 2005, 114, 1-11. [CrossRef] [PubMed]

20. Chen, C.-J.; Shih, Y.-L.; Yeh, M.-Y.; Liao, N.-C.; Chung, H.-Y.; Liu, K.-L.; Lee, M.-H.; Chou, P.-Y.; Hou, H.-Y.; Chou, J.-S.; et al. Ursolic Acid Induces Apoptotic Cell Death Through AIF and Endo G Release Through a Mitochondria-dependent Pathway in NCI-H292 Human Lung Cancer Cells In Vitro. In Vivo 2019, 33, 383-391. [CrossRef]

21. Woźniak, Ł.; Skąpska, S.; Marszałek, K. Ursolic Acid-A Pentacyclic Triterpenoid with a Wide Spectrum of Pharmacological Activities. Molecules 2015, 20, 20614-20641. [CrossRef]

22. Weng, H.; Tan, Z.-J.; Hu, Y.-P.; Shu, Y.; Bao, R.-F.; Jiang, L.; Wu, X.-S.; Li, M.; Ding, Q.; Wang, X.-A.; et al. Ursolic acid induces cell cycle arrest and apoptosis of gallbladder carcinoma cells. Cancer Cell Int. 2014, 14, 96. [CrossRef] [PubMed]

23. Kim, K.H.; Seo, H.S.; Choi, H.S.; Choi, I.; Shin, Y.C.; Ko, S.-G. Induction of apoptotic cell death by ursolic acid through mitochondrial death pathway and extrinsic death receptor pathway in MDA-MB-231 cells. Arch. Pharm. Res. 2011, 34, 1363-1372. [CrossRef]

24. Bai, N.; He, K.; Zhou, Z.; Lai, C.-S.; Zhang, L.; Quan, Z.; Shao, X.; Pan, M.-H.; Ho, C.-T. Flavonoids from Rabdosia rubescens exert anti-inflammatory and growth inhibitory effect against human leukemia HL-60 cells. Food Chem. 2010, 122, 831-835. [CrossRef]

25. Tsankova, E.T.; Kuleva, L.V.; Thanh, L.T. Composition of the Essential Oil of Adenosma bracteosum Bonati. J. Essent. Oil Res. 1994, 6, 305-306. [CrossRef]

26. Nguyen, N.H.; Pham, Q.T.; Luong, T.N.H.; Le, H.K.; Van Giau, V. Potential Antidiabetic Activity of Extracts and Isolated Compound from Adenosma bracteosum (Bonati). Biomolecules 2020, 10, 201. [CrossRef] [PubMed]

27. Von Gadow, A.; Joubert, E.; Hansmann, C.F. Comparison of the Antioxidant Activity of Aspalathin with That of Other Plant Phenols of Rooibos Tea (Aspalathus linearis), $\alpha$-Tocopherol, BHT, and BHA. J. Agric. Food Chem. 1997, 45, 632-638. [CrossRef]

28. Re, R.; Pellegrini, N.; Proteggente, A.; Pannala, A.; Yang, M.; Rice-Evans, C. Antioxidant activity applying an improved ABTS radical cation decolorization assay. Free Radic. Boil. Med. 1999, 26, 1231-1237. [CrossRef]

29. Naher, S.; Aziz, A.; Akter, M.I.; Rahman, S.M.M.; Sajon, S.R.; Mazumder, K. Anti-diarrheal activity and brine shrimp lethality bioassay of methanolic extract of Cordyline fruticosa (L.) A. Chev. leaves. Clin. Phytosci. 2019, 5, 15. [CrossRef]

30. Syahmi, A.R.M.; Vijayarathna, S.; Sasidharan, S.; Latha, L.Y.; Kwan, Y.P.; Lau, Y.L.; Shin, L.N.; Chen, Y.; Vijayaratna, S. Acute Oral Toxicity and Brine Shrimp Lethality of Elaeis guineensis Jacq., (Oil Palm Leaf) Methanol Extract. Molecules 2010, 15, 8111-8121. [CrossRef]

31. Orellana, E.A.; Kasinski, A.L. Sulforhodamine B (SRB) Assay in Cell Culture to Investigate Cell Proliferation. Bio-Protocol 2016, 6, 1984. [CrossRef] [PubMed]

32. Skehan, P.; Scudiero, M.; Vistica, D.; Bokesch, H.; Kenney, S.; Storeng, R.; Monks, A.; McMahon, J.; Warren, J.T.; Boyd, M.R. New Colorimetric Cytotoxicity Assay for Anticancer-Drug Screening. J. Natl. Cancer Inst. 1990, 82, 1107-1112. [CrossRef] [PubMed]

33. Anderson, J.E.; Goetz, C.M.; McLaughlin, J.L.; Suffness, M. A blind comparison of simple bench-top bioassays and human tumour cell cytotoxicities as antitumor prescreens. Phytochem. Anal. 1991, 2, 107-111. [CrossRef]

34. Arcanjo, D.; Albuquerque, A.; Melo-Neto, B.; Santana, L.; Medeiros, M.; Citó, A.; Arcanjo, D.D.R. Bioactivity evaluation against Artemia salina Leach of medicinal plants used in Brazilian Northeastern folk medicine. Braz. J. Boil. 2012, 72, 505-509. [CrossRef]

35. Meyer, B.; Ferrigni, N.; Putnam, J.; Jacobsen, L.; Nichols, D.; McLaughlin, J. Brine Shrimp: A Convenient General Bioassay for Active Plant Constituents. Planta Med. 1982, 45, 31-34. [CrossRef]

36. Song, M.; Charoensinphon, N.; Wu, X.; Zheng, J.; Gao, Z.; Xu, F.; Wang, M.; Xiao, H. Inhibitory Effects of Metabolites of 5-Demethylnobiletin on Human Nonsmall Cell Lung Cancer Cells. J. Agric. Food Chem. 2016, 64, 4943-4949. [CrossRef]

37. Song, M.; Wu, X.; Charoensinphon, N.; Wang, M.; Zheng, J.; Gao, Z.; Xu, F.; Li, Z.; Li, F.; Zhou, J.; et al. Dietary 5-demethylnobiletin inhibits cigarette carcinogen NNK-induced lung tumorigenesis in mice. Food Funct. 2017, 8, 954-963. [CrossRef] 
38. Seo, D.Y.; Lee, S.R.; Heo, J.-W.; No, M.-H.; Rhee, B.D.; Ko, K.S.; Kwak, H.-B.; Han, J. Ursolic acid in health and disease. Korean J. Physiol. Pharmacol. 2018, 22, 235-248. [CrossRef]

39. Liobikas, J.; Majiene, D.; Trumbeckaite, S.; Kuršvietienè, L.; Masteikova, R.; Kopustinskiene, D.M.; Savickas, A.; Bernatoniene, J. Uncoupling and Antioxidant Effects of Ursolic Acid in Isolated Rat Heart Mitochondria. J. Nat. Prod. 2011, 74, 1640-1644. [CrossRef]

40. Kashyap, D.; Tuli, H.S.; Punia, S.; Sharma, A.K.; Sharma, A. Ursolic Acid and Oleanolic Acid: Pentacyclic Terpenoids with Promising Anti-Inflammatory Activities. Recent Pat. Inflamm. Allergy Drug Discov. 2016, 10, 21-33. [CrossRef]

41. Jesus, J.A.; Lago, J.H.G.; Laurenti, M.D.; Yamamoto, E.; Passero, L.F.D. Antimicrobial Activity of Oleanolic and Ursolic Acids: An Update. Evid.-Based Complement. Altern. Med. 2015, 2015, 1-14. [CrossRef] [PubMed]

42. Shishodia, S.; Majumdar, S.; Banerjee, S.; Aggarwal, B.B. Ursolic acid inhibits nuclear factor-kappaB activation induced by carcinogenic agents through suppression of IkappaBalpha kinase and p65 phosphorylation: Correlation with down-regulation of cyclooxygenase 2, matrix metalloproteinase 9, and cyclin D1. Cancer Res. 2003, 63, 4375-4383. [PubMed]

43. Sultana, N. Clinically useful anticancer, antitumor, and antiwrinkle agent, ursolic acid and related derivatives as medicinally important natural product. J. Enzym. Inhib. Med. Chem. 2011, 26, 616-642. [CrossRef]

44. Jayaprakasam, B.; Olson, L.K.; Schutzki, R.E.; Tai, M.-H.; Nair, M.G. Amelioration of Obesity and Glucose Intolerance in High-Fat-Fed C57BL/6 Mice by Anthocyanins and Ursolic Acid in Cornelian Cherry (Cornus mas). J. Agric. Food Chem. 2006, 54, 243-248. [CrossRef] [PubMed]

45. Sundaresan, A.; Radhiga, T.; Pugalendi, K.V. Effect of ursolic acid and Rosiglitazone combination on hepatic lipid accumulation in high fat diet-fed C57BL/6J mice. Eur. J. Pharmacol. 2014, 741, 297-303. [CrossRef]

46. Aggarwal, V.; Tuli, H.S.; Varol, A.; Thakral, F.; Yerer, M.B.; Sak, K.; Varol, M.; Jain, A.; Khan, A.; Sethi, G. Role of Reactive Oxygen Species in Cancer Progression: Molecular Mechanisms and Recent Advancements. Biomolecules 2019, 9, 735. [CrossRef] [PubMed]

47. Ziech, D.; Franco, R.; Georgakilas, A.G.; Georgakila, S.; Malamou-Mitsi, V.; Schoneveld, O.; Pappa, A.; Panagiotidis, M. The role of reactive oxygen species and oxidative stress in environmental carcinogenesis and biomarker development. Chem. Interact. 2010, 188, 334-339. [CrossRef] [PubMed]

48. Sharma, N.; Dobhal, M.P.; Joshi, Y.C.; Chahar, M.K. Flavonoids: A versatile source of anticancer drugs. Pharmacogn. Rev. 2011, 5, 1-12. [CrossRef]

49. Ghasemzadeh, A.; Jaafar, H. Profiling of phenolic compounds and their antioxidant and anticancer activities in pandan (Pandanus amaryllifolius Roxb.) extracts from different locations of Malaysia. BMC Complement. Altern. Med. 2013, 13, 341. [CrossRef]

50. Grever, M.R.; Schepartz, S.A.; Chabner, B.A. The National Cancer Institute: Cancer drug discovery and development program. Semin. Oncol. 1992, 19, 622-638. [PubMed]

51. Goldin, A.; Venditti, J.M.; Macdonald, J.S.; Muggia, F.M.; Henney, J.E.; Devita, V.T., Jr. Current results of the screening program at the Division of Cancer Treatment, National Cancer Institute. Eur. J. Cancer 1981, 17, 129-142. [CrossRef]

52. Protocols for screening chemical agents and natural products against animal tumors and other biological systems: Drug Evaluation Branch. Nat. Cancer Inst. 1962, 3, 1-107.

53. Yin, R.; Li, T.; Tian, J.X.; Xi, P.; Liu, R.H. Ursolic acid, a potential anticancer compound for breast cancer therapy. Crit. Rev. Food Sci. Nutr. 2017, 58, 568-574. [CrossRef]

54. Yamaguchi, H.; Noshita, T.; Kidachi, Y.; Umetsu, H.; Hayashi, M.; Komiyama, K.; Funayama, S.; Ryoyama, K. Isolation of Ursolic Acid from Apple Peels and Its Specific Efficacy as a Potent Antitumor Agent. J. Health Sci. 2008, 54, 654-660. [CrossRef]

55. Jäger, S.; Trojan, H.; Kopp, T.; Laszczyk, M.N.; Scheffler, A. Pentacyclic Triterpene Distribution in Various Plants-Rich Sources for a New Group of Multi-Potent Plant Extracts. Molecules 2009, 14, 2016-2031. [CrossRef]

56. Liu, P.; Du, R.; Yu, X. Ursolic Acid Exhibits Potent Anticancer Effects in Human Metastatic Melanoma Cancer Cells (SK-MEL-24) via Apoptosis Induction, Inhibition of Cell Migration and Invasion, Cell Cycle Arrest, and Inhibition of Mitogen-Activated Protein Kinase (MAPK)/ERK Signaling Pathway. Med. Sci. Monit. 2019, 25, 1283-1290. [PubMed]

57. Feng, X.; Su, X. Anticancer effect of ursolic acid via mitochondria-dependent pathways. Oncol. Lett. 2019, 17, 4761-4767. [CrossRef] 
58. Rieger, A.M.; Nelson, K.L.; Konowalchuk, J.D.; Barreda, D.R. Modified annexin V/propidium iodide apoptosis assay for accurate assessment of cell death. J. Vis. Exp. 2011, 2011, e2597. [CrossRef] [PubMed]

59. Redza-Dutordoir, M.; Averill-Bates, D.A. Activation of apoptosis signalling pathways by reactive oxygen species. Biochim. Biophys. Acta (BBA) Mol. Cell Res. 2016, 1863, 2977-2992. [CrossRef] [PubMed]

60. Vo, V.G.; An, S.S.A.; Hulme, J.P. Mitochondrial therapeutic interventions in Alzheimer's disease. J. Neurol. Sci. 2018, 395, 62-70.

61. Fiers, W.; Beyaert, R.; Declercq, W.; Vandenabeele, P. More than one way to die: Apoptosis, necrosis and reactive oxygen damage. Oncogene 1999, 18, 7719-7730. [CrossRef] [PubMed]

62. Mates, J.M.; Sanchez-Jimenez, F.M. Role of reactive oxygen species in apoptosis: Implications for cancer therapy. Int. J. Biochem. Cell Biol. 2000, 32, 157-170. [CrossRef]

63. Suski, J.M.; Lebiedzińska-Arciszewska, M.; Bonora, M.; Pinton, P.; Duszynski, J.; Wieckowski, M.R. Relation Between Mitochondrial Membrane Potential and ROS Formation. Methods Mol. Biol. 2011, 810, 183-205.

64. Waterhouse, N.J.; Goldstein, J.C.; Von Ahsen, O.; Schuler, M.; Newmeyer, D.D.; Green, D.R. Cytochrome C Maintains Mitochondrial Transmembrane Potential and Atp Generation after Outer Mitochondrial Membrane Permeabilization during the Apoptotic Process. J. Cell Biol. 2001, 153, 319-328. [CrossRef] [PubMed]

65. Ricci, J.E.; Gottlieb, R.A.; Green, D.R. Caspase-mediated loss of mitochondrial function and generation of reactive oxygen species during apoptosis. J. Cell Biol. 2003, 160, 65-75. [CrossRef]

66. Xie, L.-L.; Shi, F.; Tan, Z.; Li, Y.; Bode, A.M.; Cao, Y. Mitochondrial network structure homeostasis and cell death. Cancer Sci. 2018, 109, 3686-3694. [CrossRef]

67. Zhou, W.; Yuan, X.; Zhang, L.; Su, B.; Tian, D.; Li, Y.; Zhao, J.; Wang, Y.-M.; Peng, S. Overexpression of HO-1 assisted PM2.5-induced apoptosis failure and autophagy-related cell necrosis. Ecotoxicol. Environ. Saf. 2017, 145, 605-614. [CrossRef]

68. Eisenberg-Lerner, A.; Bialik, S.; Simon, H.-U.; Kimchi, A. Life and death partners: Apoptosis, autophagy and the cross-talk between them. Cell Death Differ. 2009, 16, 966-975. [CrossRef]

69. Peixoto, M.S.; Galvão, M.F.D.O.; De Medeiros, S.R.B. Cell death pathways of particulate matter toxicity. Chemosphere 2017, 188, 32-48. [CrossRef]

70. Greenwell, M.; Rahman, P.K. Medicinal Plants: Their Use in Anticancer Treatment. Int. J. Pharm. Sci. Res. 2015, 6, 4103-4112.

71. Seca, A.M.L.; Pinto, D.C.G.A. Plant Secondary Metabolites as Anticancer Agents: Successes in Clinical Trials and Therapeutic Application. Int. J. Mol. Sci. 2018, 19, 263. [CrossRef]

72. Santos, U.P.; Campos, J.F.; Torquato, H.F.V.; Paredes-Gamero, E.J.; Carollo, C.A.; Estevinho, L.M.; Souza, K.D.P.; Dos Santos, U.P. Antioxidant, Antimicrobial and Cytotoxic Properties as Well as the Phenolic Content of the Extract from Hancornia speciosa Gomes. PLoS ONE 2016, 11, e0167531. [CrossRef] [PubMed]

73. Casagrande, J.C.; Macorini, L.F.B.; Antunes, K.Á.; Dos Santos, U.P.; Campos, J.F.; Dias-Júnior, N.M.; Sangalli, A.; Cardoso, C.A.L.; Vieira, M.D.C.; Rabelo, L.A.; et al. Antioxidant and Cytotoxic Activity of Hydroethanolic Extract from Jacaranda decurrens Leaves. PLoS ONE 2014, 9, e112748. [CrossRef]

74. Campos, J.F.; Espindola, P.P.D.T.; Torquato, H.F.V.; Vital, W.; Justo, G.Z.; Silva, D.B.; Carollo, C.A.; Souza, K.D.P.; Paredes-Gamero, E.J.; Dos Santos, E.L. Leaf and Root Extracts from Campomanesia adamantium (Myrtaceae) Promote Apoptotic Death of Leukemic Cells via Activation of Intracellular Calcium and Caspase-3. Front. Pharmacol. 2017, 8, 466. [CrossRef] [PubMed]

75. Baldivia, D.S.; Leite, D.F.; De Castro, D.T.H.; Campos, J.F.; Dos Santos, U.P.; Paredes-Gamero, E.J.; Carollo, C.A.; Silva, D.B.; Souza, K.D.P.; Dos Santos, E.L. Evaluation of In Vitro Antioxidant and Anticancer Properties of the Aqueous Extract from the Stem Bark of Stryphnodendron adstringens. Int. J. Mol. Sci. 2018, 19, 2432. [CrossRef] [PubMed]

Sample Availability: Samples of the compounds are available from the authors. 